Journal of Telenursing (JOTING)

Volume 1, Nomor 2, Desember 2019

e-ISSN: 2684-8988

p-ISSN: 2684-8996

DOI: https://doi.org/10.31539/joting.v1i2.899

\title{
KESEJAHTERAAN PSIKOLOGIS DAN KUALITAS HIDUP PENDERITA DIABETES MELLITUS TYPE 2
}

\author{
Sasmiyanto \\ Universitas Muhammadiyah Jember \\ sasmiyanto1@gmail.com
}

\begin{abstract}
ABSTRAK
Tujuan penelitian ini adalah ingin membuktikan adanya korelasi antara kesejahteraan psikologis dan kualitas hidup penderita diabetes mellitus type 2 di Bondowoso. Jenis penelitian ini adalah penelitian korelasional dengan pendekatan cross sectional. Hasil penelitian berdasarkan uji statistik didapatkan rerata nilai kesejahteraan psikologis klien 120,5778 yang dapat dikatakan cukup baik. Kualitas hidup responden memiliki rerata skor 53,389 yang dapat dikatakan cukup baik. Hasil analisa statistik menunjukkan p value 0.004. Simpulan, ada hubungan signifikan antara kesejahteraan psikologis dengan kualitas hidup penderita diabetes mellitus. Pengaruh dari efek psikologis kedalam kondisi tubuh sangat besar.
\end{abstract}

Kata Kunci: Diabetes Mellitus Type 2, Kesejahteraan Psikologis, Kualitas Hidup

\section{ABSTRACT}

The purpose of this study is to prove the correlation between psychological well-being and quality of life of people with type 2 diabetes mellitus in Bondowoso. This type of research is a correlational study with a cross sectional approach. The results of the study based on statistical tests found the average value of the psychological well-being of clients 120.5778 which can be said to be quite good. The quality of life of respondents has an average score of 53,389 which can be said to be quite good. The results of statistical analysis show that the $p$ value is 0.004. Conclusion, there is a significant relationship between psychological well-being and quality of life of people with diabetes mellitus. The effect of psychological effects on the condition of the body is huge.

Keywords: Diabetes Mellitus Type 2, Psychological Well-Being, Quality of Life 


\section{PENDAHULUAN}

Pergeseran trend penyakit yang terjadi di Indonesia menunjukkan kecenderungan tingginya prevalensi penyakit tidak menular, yang salah satunya adalah diabetes mellitus. Diabetes mellitus type 2 merupakan salah satu penyakit kronis yang banyak terjadi di Indonesia. Diabetes mellitus type 2 merupakan penyakit akibat gangguan metabolik yang disebabkan oleh insufisiensi sekresi insulin oleh pankreas atau ketidakefektifan sekresi insulin ke seluruh tubuh. Hal ini selanjutnya akan berdampak pada tingginya kadar gula darah penderita dan memunculkan manifestasi klinis seperti mudah haus, mudah lapar, sering buang air kecil, kelemahan, kesemutan, gatal, mata kabur dan pruritus di area vulva.

Diabetes mellitus (DM) merupakan suatu kelainan pada seseorang yang ditandai dengan naiknya kadar glukosa dalam darah (Hiperglikemia) yang diakibatkan karena kekurangan Insulin (Padila, 2012). DM menjadi salah satu penyakit kronis dengan angka kejadian tinggi dimana WHO memperkirakan penyakit DM akan menjadi epidemi global pada abad 21 dan 70\% kasus DM ada di negara-negara berkembang (Tol et al., 2013). Termasuk diantaranya adalah negara Indonesia. Diagnosa DM tipe 2 serta banyaknya perawatan yang dilakukan menimbulkan perubahan atau ketidakseimbangan yang meliputi biologi, psikologi, sosial dan spiritual pasien serta memberikan dampak pada kehidupan keluarga pasien (WHO, 2014).

Diabetes mellitus merupakan kelompok penyakit metabolik dengan karakteristik hiperglikemia yang terjadi karena kelainan sekresi insulin, kerja insulin atau keduanya yang harus dilakukan pengelolaan sehingga tidak terjadi komplikasi lebih lanjut. Pengelolaan diabetes mellitus meliputi edukasi, terapi gizi medis, latihan jasmani dan intervensi farmakologis yang dapat diberikan melalui edukasi terpadu (Yulishati, 2014). Diabetes mellitus penyakit yang paling kompleks dan membutuhkan perhatian maupun usaha dalam pengeolaannya (Kusumadewi, 2011).

Mahmoud et al., (2018) menyebutkan berdasarkan data International Diabetes Federation, 285 juta orang di seluruh dunia mengidap diabetes mellitus dan jumlah ini akan terus meningkat hinga mencapai 438 juta orang di tahu 2030 dengan dua pertiga diantaranya terjadi di negara berkembang. Jumlah penderita diabetes mellitus dengan gangguan tes toleransi glukosa juga diprediksi akan meningkat dari angka 344 juta di tahun 2010 menjadi 472 juta jiwa di tahun 2030, dan secara tidak langsung hal ini menunjukkan peningkatan kejadian obesitas atau overweight sebagai salah satu faktor resiko diabetes mellitus.

Perjalanan penyakit diabetes mellitus sebagai salah satu penyakit kronis beresiko menimbulkan berbagai macam komplikasi. Berbagai komplikasi yang dapat terjadi adalah komplikasi mikrovaskuler seperti retinopati dan neuropati serta komplikasi makrovaskuler seperti infark miokard akut, angina pektorism stroke dan diabetic foot. Komplikasi ini berdampak pada kualitas hidup penderita diabetes mellitus.

Faktor sosio-psikologis memegang peranan penting dalam keberhasilan pengobatan dan pengontrolan gejala diabetes mellitus dan komplikasinya. Mojahed et al., (2019) menyebutkan bahwa kesejahteraan psikologis berdampak langsung terhadap kesehatan mental dan berdampak tidak langsung terhadap kesehatan fisik atau komplikasi diabetes mellitus yang dialami, dengan kata lain seseorang dengan kesejahteraan psikologis yang baik akan cenderung lebih sehat baik secara fisik dan mental. Lebih jauh kesejateraan psikologis lebih mengarah pada kemampuan dan kekuatan seseorang dibandingkan berfokus pada penyakit dan kelemahan yang ditimbulkan penyakit. Ryff dalam Mojahed et al., (2019) megidentifikasi enam kriteria 
kesejahteraan psikologis diantaranya penerimaan diri, tujuan hidup, kematangan personal, hubungan positif, otonomi dan kemampuan mengontrol lingkungan. Kesejahteraan pada penderita diabetes mellitus diasosiasikan dengan kemampuan klien untuk beradaptasi terhadap kebutuhan perawatan diabetes, mempertahankan hubungan sosial dan kemampuan mencegah komplikasi (Tirumalesh \& Candraiah, 2017).

Perawatan jangka panjang yang harus dijalani pasien DM sangat sulit dikontrol secara efektif, sehingga sangat penting memperhatikan aspek psikologis selain aspek fisik pasien DM tipe 2. Psychological Well Being (PWB) merupakan salah satu bagian dari area psikologi positif umum yang disebut sebagai subjective well being (SWB) yang merupakan suatu ukuran berfungsi secara positif dalam tingkat individu. Pasien DM tipe2 yang memiliki PWB yang rendah akan berakibat pada rendahnya tingkat perawatan diri (self care) (Peyrot et al., 2005). Tingkat perawatan diri yang rendah akan mengakibatkan peningkatan terjadinya komplikasi (Davis, 2010; Kusnanto, 2013). Menurut WHO, Psychological Well Being adalah sebuah appraisal subyektif fungsiseorang individu dalam realisasi-diri (Keyes, 2013).

Seperti yang dijelaskan sebelumnya bahwa kesejahteraan psikologis berdampak langsung pada kesehatan mental penderita diabetes mellitus. Kesehatan mental dalam hal ini diukur dengan menggunakan parameter kualitas hidup. Kualitas hidup merupakan persepsi individu atas posisinya dalam kehidupan dalam konteks budaya dan sistem nilai dan kaitannya dengan tujuan, harapan dan standar yang ada.

Zurita et al., (2018) menyebutkan bahwa kualitas hidup telah ditetapkan sebagai salah satu parameter untuk mengukur keberhasilan perawatan diabetes mellitus. Pengobatan tidak hanya diarahkan untuk menyembuhkan penyakit tapi juga untuk mengembalikan fungsi kesehatan. Sehingga perawatan diabates mellitus tidak hanya menekankan pada kuantitas hidup namun juga kualitas. Secara umum kualitas hidup pada penyakit kronis didefinisikan sebagai keseluruhan proses evaluasi individu terhadap hal-hal yang berpengaruh dalam hidupnya, baik secara internal maupun eksternal.

Tujuan peneliti adalah ingin membuktikan adanya korelasi antara kesejahteraan psikologis dan kualitas hidup penderita diabetes mellitus type 2 di Bondowoso.

\section{METODE PENELITIAN}

\section{Desain Penelitian}

Penelitian ini adalah penelitian korelasional dengan pendekatan cross sectional yang dilakukan di wilayah Kabupaten Bondowoso.

\section{Participant}

Populasi pada penelitian ini adalah pasien diabetes mellitus yang berkunjung ke Klinik Holistic Care Bondowoso selama bulan Meret - Juni 2019 dengan rerata kunjungan sebanyak 243 orang. Responden pada penelitian ini adalah 90 orang penderita diabetes mellitus yang diambil dengan mengunakan purposive sampling. Kriteria inklusi pada penelitian ini adalah responden berusia lebih dari 17 tahun, mampu baca tulis, kooperatif, dapat mengambil keputusan sendiri.

\section{Data Collection Procedure}

Data penelitian diambil dengan menggunakan kuisioner. Pasien yang datang berkunjung ke klinik Holistic Care dan dinilai layak menjadi responden diminta untuk menandatangani inform consent dan selanjutnya diminta untuk mengisi kuisioner. 


\section{Ethical Consideration}

Penelitian ini dilakukan seteleah mendapat persetujuan dari Komisi Etik di Fakultas Ilmu Kesehatan Universitas Muhammadiyah Jember. Peneliti memberikan penjelasan kepada calon responden mengenai tujuan, metode, manfaat, resiko serta prosedur pengambilan data selama proses penelitian. Peneliti menjamin kerahasiaan pada responden dan memberikan hak kepada responden bahwa responden dapat keluar saat proses penelitian kapanpun tanpa implikasi untuk perlakuan selanjutnya.

\section{Statistik Analisis}

Analisa data dilakukan dengan menggunakan software SPSS 20. Deskriptif statistik dilakukan untuk mengetahui karakteristik responden. Uji parametrik korelasi Pearson dilakukan untuk mengetahui hubungan kesejahteraan psikologis dan kualitas hidup pada penderita diabetes mellitus di Bondowoso.

\section{HASIL PENELITIAN}

Tabel 1.

Distribusi Karakteriktik Responden

\begin{tabular}{lccc}
\hline \multicolumn{1}{c}{ Karakteristik } & Jumlah & Persentase & \\
\hline Umur & & & \\
& $31-40$ & 9 & 10 \\
& $40-50$ & 30 & 33 \\
& $50-60$ & 45 & 50 \\
& $60-70$ & 6 & 7 \\
\hline Jenis Kelamin & Laki - laki & 12 & 13 \\
& Perempuan & 78 & 87 \\
\hline Tingkat pendidikan & SD & 9 & \\
& SMP & 24 & 10 \\
& SMA & 51 & 66 \\
& Sarjana & 6 & 7 \\
\hline Pekerjaan & PNS & 6 & 7 \\
& Wiraswasta & 60 & 67 \\
& Buruh & 9 & 10 \\
& Ibu Rumah Tangga & 15 & 16 \\
\hline Status Pernikahan & Menikah & 90 & 100 \\
\hline Keikutsertaan Asuransi Kesehatan & Ya & 60 & 67 \\
& Tidak & 30 & 33 \\
\hline
\end{tabular}

Berdasarkan tabel 1 dapat dilihat bahwasanya responden yang terlibat dalam penelitian ini $50 \%$ berusia 50 - 60 tahun, $87 \%$ berjenis kelamin perempuan, $66 \%$ lulus dari SMA, 67\% bekerja sebagai wiraswasta, seluruhnya menikah dan $67 \%$ memiliki asuransi kesehatan. 
Tabel. 2

Riwayat Penyakit Diabetes Mellitus

\begin{tabular}{llcc}
\hline Karaketeristik & & Jumlah & Prosentase \\
\hline Komorbid & Ya & 75 & 84 \\
& Tidak & 15 & 16 \\
\hline Komplikasi & Ya & 60 & 67 \\
& Tidak & 30 & 33 \\
\hline Lama sakit & Kurang dari 1 tahun & & \\
& Lebih dari 1 tahun & 15 & 16 \\
& & 75 & 84 \\
\hline Gula darah acak & 200 mg/dl & 24 & 27 \\
& $>200$ mg/dl & 66 & 73 \\
\hline BMI & Underweight & & \\
& Normal & 30 & 33 \\
& Overweight & 60 & 67 \\
& Obesitas & & \\
\hline
\end{tabular}

Berdasarkan tabel 2 karakteristik riwayat penyakit diabetes mellitus responden dapat dijelaskan sebagai berikut $67 \%$ klien tidak memiliki penyakit penyerta, $67 \%$ responden memiliki komplikasi berupa diabetic foot, $84 \%$ responden menderit penyakit lebih dari setahun, 73\% responden memiliki kadar gula darah $>200 \mathrm{mg}$, dan $67 \%$ responden memiliki indek massa tubuh overweight.

Tabel. 3

Uji Statistik Korelasi Kesejahteraan Psikologis dan Kualitas Hidup Penderita Diabetes Mellitus Type 2

\begin{tabular}{|c|c|c|c|c|}
\hline Variabel & Minimal & Maximal & Mean & Std. Deviasi \\
\hline Kesejahteraan psikologis & 60 & 135 & 120,5778 & 11,27389 \\
\hline Kualitas hidup & 39 & 70 & 53,389 & 8,17875 \\
\hline $\mathrm{p}$ val & .004 & tion coef & t 0.303 & \\
\hline
\end{tabular}

Berdasarkan data pada tabel 3 dapat dilihat bahwa pada variabel kesejahteraan psikologis nilai rerata responden adalah 120,5778 dengan nilai kesejahteraan psikologis terendah adalah 60 dan nilai kejehateraan psikologis tertinggi adalah 135. Dengan demikian dapat dikatakan bahwa kesejahteraan psikologis responden berada pada rentang cukup baik. Sedangkan kualitas hidup responden memiliki nilai rerata 53,389 dengan nilai minimum 30 dan nilai maksimum 70 sehingga dapat dikatakan kualitas hidup responden cukup baik.

\section{PEMBAHASAN}

\section{Karakteristik Umum Responden}

Berdasarkan data pada tabel 1 dapat dilihat bahwa berdasarkan umur, mayoritas responden berusia 50 - 60 tahun. Usia yang semakin tua menunjukkan bahwa diabetes mellitus juga merupakan salah satu penyakit degeneratif yang akan prevalensinya meningkat sejalan dengan peningkatan usia akibat penurunan fungsi pankreas dalam mensekresikan insulin. Hal ini sejalan dengan penelitian Alva et al., (2017) yang menyebutkan resiko diabetes mellitus mengalami peningkatan sejalan dengan umur. 
Berdasarkan jenis kelamin mayoritas responden berjenis kelamin perempuan sebanyak $87 \%$. Perempuan beresiko mengalami gangguan metabolik akibat ketidakseimbangan hormonal. Kondisi seperti menarche lebih awal, siklus tidak teratur, tingginya kadar hormon androgen (PCOS) dan memiliki riwayat DM gestasional menyebabkan perempuan lebih beresiko menderita diabetes mellitus type 2 (Harraiter \& Kautzky, 2018).

Tabel 1 menunjukkan bahwa mayoritas responden merupakan lulusan SMA, bekerja sebagai wiraswasta, seluruhnya menikah, memiliki asuransi kesehatan dan memiliki riwayat penyakit penyerta. Selain itu pada tabel 1 juga disebutkan bahwa mayoritas responden mengalami komplikasi berupa diabetic foot sebanyak 67\%, 84\% mengalami sakit selama lebih dari 1 tahun, 73\% responden memiliki kadar gula darah acak lebih dari $200 \mathrm{mg} / \mathrm{dl}$ dan $87 \%$ responden memiliki indek massa tubuh normal. Data ini menunjukkan bahwa penyakit diabetes mellitus yang diderita oleh responden bersifat kronis dan responden belum melakukan manajemen pengelolaan penyakit terlihat dari data riwayat penyakit yang telah lebih dari satu tahun dan tingginya angka kejadian komplikasi diabetic foot.

\section{Kesejahteraan Psikologis Penderita Diabetes Mellitus}

Berdasarkan uji statistik didapatkan rerata nilai kesejahteraan psikologis responden adalah 120,5778 atau dengan kata lain responden memiliki kesejahteraan psikologis cukup baik.

Massey et al., (2017) menyebutkan bahwa distres psikologis dan gangguan afek negatif banyak terjadi pada penderita diabetes mellitus type 2. Kondisi psikologis akan sangat mempengaruhi perilaku kesehatan dan outcome klinis pada penderita diabetes mellitus type 2. Disisi lain, karakteristik psikologis yang positif membawa dampak yang positif pula, membawa kepribadian konstruktif dan berperan penting dalam meningkatkan outcome perawatan penderita.

Berdasarkan karakteristik responden, terlihat bahwa penyakit diabetes mellitus yang diidap oleh responden berada pada fase kronis. Hal ini ditandai dengan data yang menunjukkan bahwa mayoritas responden telah didiagnosa diabetes mellitus sejak lebih dari setahun yang lalu dan mayoritas repsonden memiliki komplikasi diabetic foot. Hal ini menandakan bahwa pengontrolan gejala diabetes mellitus yang dilakukan oleh klien tidak bagus. Bersadarkan hasil wawancara yang dilakukan oleh peneliti, didapatkan data yang menyebutkan bahwa klien jarang melakukan kontrol gula darah di layanan fasilitas kesehatan, tidak mengontrol asupan makanan dan responden pernah merasa berputus asa karena komplikasi diabetic foot yang dialaminya. Kronologis yang disampaikan oleh responden menunjukkan responden pernah mengalami distres psikologis akibat kondisi yang dialaminya. Komplikasi diabetic foot yang dialami oleh responden sedikit banyak akan mempengaruhi kondisi psikologis klien. Diabetic foot akan menghalagi klien untuk beraktifitas, mempengaruhi pelaksanaan peran klien dalam kehidupan sehari -hari dan juga berpengaruh body image responden yang pada akhirnya mempengaruhi interaksi sosial responden.

Penanganan diabetes mellitus membutuhkan waktu yang lama bahkan pengontrolan gejala diabetes mellitus membutuhkan waktu seumur hidup. Kondisi ini sedikit banyak menjadi stresor tersendiri baik bagi penderita maupun keluarga. Apabila motivasi penderita dan keluarga tidak dipertahankan selama proses pengontrolan gejala diabetes mellitus akan menyebabkan kondisi klien tidak terkontrol dan jatuh pada 
kondisi lebih berat dengan munculnya komplikasi diabetes mellitus yang pada akhirnya akan memperberat stresor.

Penanganan diabetes mellitus dan komplikasinya ditujukan untuk menurunkan manifestasi klinis dan meningkatkan kondisi psikologis klien. Responden pada penelitian ini mayoritas mendapatkan treatment perawatan luka untuk mengatasi diabetic foot yang diderita oleh klien. Beberapa klien yang telah melakukan perawatan mendapati perubahan diabetic foot yang mereka alami menjadi lebih baik dan sejalan dengan perbaikan kondisi luka yang dialami responden menyatakan mereka memiliki gambaran diri yang lebih baik, tidak merasa malu pada orang sekitar karena telah mampu berperan, beraktifitas dan bekerja seperti sedia kala dan interaksi sosialnya mulai membaik. Kondisi ini yang diperkirakan menyebabkan responden memiliki psikologis postitif sehingga kesejahteraan psikologisnya meningkat.

\section{Kualitas Hidup Penderita Diabetes Mellitus}

Kualitas hidup merupakan persepsi individu atas posisinya dalam kehidupan dalam konteks budaya dan sistem nilai dan kaitannya dengan tujuan, harapan dan standar yang ada. Berdasarkan hasil penelitian kualitas hidup responden memiliki nilai skor 53,389 dengan nilai skor terendah adalah 39 dan terendah adalah 70 . Dengan demikian dapat disimpulkan kualitas hidup responden cukup baik.

Diabetes mellitus merupakan kelainan metabolik yang bersifat kronis. Diabetes mellitus dapat menimbulkan berbagai komplikasi yang dapat menimbulkan memanjangnya masa perawatan dan meningkatkan biaya perawatan. Komplikasi makrovaskuler yang dapat ditimbulkan oleh diabetes mellitus type 2 adalah infark miokard akut, stroke, dan kelainan arteri perifer. Sedangkan komplikasi mikrovaskuler meliputi neuropati, nefropati hingga diabetic foot. Komplikasi ini membawa dampak secara fisik maupun emosional yang dapat mempengaruhi kualitas hidup pasien. Sifat penyakit yang kronis dan tingkat kesulitan mengontrol penyakit dapat mempengaruhi mood dan harga diri, mengarah pada frustasi dan depresi, pembatasan makanan dan pola kehidupan seksual yang kesemuanya berkontribusi negatif terhadap kualitas hidup penderita.

Zurita et al., (2018) menyebutkan ada beberapa hal yang dapat mempengaruhi kualitas hidup diantaranya adalah adanya stresor, keteraturan berobat, penggunaan insulin, status pernikahan dan adanya penyakit penyerta. Berdasarkan data pada tabel 1 dapat dilihat bahwa $67 \%$ responden memiliki komplikasi. Hampir seluruh responden (63\%) memiliki komplikasi berupa diabetic foot. Diabetic foot merupakan kondisi komplikasi yang dapat mempengaruhi kehidupan responden dikarenakan gangguan harga diri akibat diabetic foot. Responden dengan diabetic foot yang tidak terkontrol akan mengalami gangguan dalam melaksanakan peran dan aktifitasnya. Dengan demikian dapat dikatakan bahwa diabetic foot meupakan suatu stresor yag dapat mengganggu integritas kualitas hidup penderita.

Tabel 2 menunjukkan 84\% responden telah mengidap diabetes mellitus. Lama sakit ditambah dengan banyaknya responden yang memiliki komplikasi diabetik menandakan bahwa pengontrolan gejala diabetes mellitus tidak dilakukan dengan baik. Pengontrolan gejala diabetes mellitus waktu yang cukup lama, bahkan seumur hidup, dan membutuhkan motivasi baik dari klien maupun keluarga. Dalam penelitian ini seluruh responden menikah dan hidup bersama dengan pasangannya dan atau keluarganya. Berada di tengah keluarga mampu memberikan suatu dorongan yang akan menimbulkan motivasi dan memperbaiki kualitas hidup responden. Namun di sisi lain 
waktu pengobatan yang lama ditambah dengan adanya komplikasi diabetic foot yang dialami oleh klien akan menimbulkan suatu stresor baik bagi klien dan juga keluarga sebagai care giver klien. Stresor ini dapat mempengaruhi menurunkan kualitas hidup klien.

\section{Hubungan Kesejahteraan Psikologis dan Kualitas Hidup Penderita Diabetes Mellitus}

Hasil uji statistik dengan menggunakan korelasiPearson menunjukkan $\mathrm{p}$ value $0.004<\alpha 0.05$ yang berarti ada hubungan signifikan antara kesejahteraan psikologis dan kualitas hidup penderita diabetes mellitus.

Tirumalesh \& Chandraiah (2017) menyebutkan bahwa diabetes mellitus sebagai salah satu penyakit kronis yang memakan waktu lama dalam penatalaksanaannya merupakan salah satu stresor berat baik bagi penderita dan keluarganya. Diabetes mellitus membawa berbagai perubahan dalam banyak hal diantaranya diet, kontrol pengobatan yang lebih sering, pengobatan, komplikasi dan perubahan gaya hidup lainnya membawa suatu stresor tersendiri bagi penderitanya.

Stresor tersebut akan meinmbulkan distres psikologis bagi penderita diabetes mellitus yang pada akibatnya akan menyebabkan munculknya gejala depresi pada penderita. Sejalan dengan hasil penelitian Massey et al., (2017) yang menyebutkan bahwa distres psikologis akan menimbulkan depresi. Depresi akan mempengaruhi hoemostasis tubuh dan kualitas hidup pendiritanya. Depresi yang ditimbulkan akan menyebebkan timbulnya gangguan pengendalian glukosa, ganguan status fungsional, komplikasi multi organ dan kematian. Depresi akan menyebabkan terjadinya peningkatan kadar glukosa darah, kenaikan kadar gula darah yang tidak terkontrol akan membawa perubahan dimana secara umum kesehatan responden menjadi tidak baik akibat pengaruh kadar gula yang tinggi menyebabkan secara umum kesehatan respondenmenurun sehingga skor kualitas hidup akan menurun.

Lebih lanjut depresi berhubungan dengan buruknya kualitas hidup. Pengobatan secara farmakologis maupun non farmakologis mampu memberikan perbaikan kondisi pada penderita diabetes. Perubahan ini mempu meningkatkan mood dan kualitas hidup.

Peningkatan kualitas hidup penderita diabetes mellitus merupakan tujuan utama dalam proses perawatan penderita diabetes mellitus. Penatalaksanan yang mengarah pada perawatan luka membantu mengatasi kondisi komplikasi. Ketika luka diabetic foot yang dialami oleh pasien membaik dan responden mampu kembali hidup sesuai dengan peran, fungsi dan tujuannya. Luka yang membaik akan membantu responden mempertahankan interaksi sosial, dan memungkinkan responden kembali pada aktifitas dan perannya. Kondisi ini akan menumbuhkan sisi positif dari dalam diri penderita. Seperti yang telah disebutkan sebelumnya bahwa psikologis positif yang muncul pada klien akan mempengaruh paramater kesehatan lainnya. Psikologis positif akan membuat kadar gula berada pada kadar yang tidak terlalu tinggi dan stabil. Kondisi kadar gula darah yang stabil akan berpengaruh terhadap persepsi kesehatan responden secara umum sehingga responden mampu memiliki kualitas hidup yang baik 


\section{SIMPULAN}

Mayoritas responden yang terlibat dalam penelitian ini adalah perempuan, beragama slam, berusia 50 -60 tahun, bekerja sebagai wiraswasta

Kondisi responden yang berkaitan dengan diabetes mellitus adalah mayoritas responden memiliki komorbid berupa hipertensi, memiliki komplikasi diabetic foot, sakit lebih dari setahun dan memiliki indeks massa tubuh overweight.

Mayoritas responden penderita diabetes mellitus memiliki kesejahteraan psikologis cukup baik. Mayoritas responden penderita diabetes mellitus memiliki kualitas hidup cukup baik. Kesejahteraan psikologis memiliki korelasi signifikan dengan kualitas hidup penderita diabetes mellitus.

\section{SARAN}

Berdasatkan hasil penelitian ini diharapkan seluruh penyedia layanan kesehatan harus memperhatikan kesejahteraan psikologis di samping kesehatan fisik sebagai outcome layanan. Besarnya pengaruh dari efek psikologis kedalam kondisi tubuh sangat besar. Sehingga diupayakan keluarga sebagai orang terdekat klien selalu memberi dukungan pada klien.

\section{DAFTAR PUSTAKA}

Alva, M., Hoerger, T., Zhang, P. \& Greg, E. (2017). Identifying Risk for Type 2 Diabetes in Different Age Cohort : Does One Size Fit All?. BMJ Open Diabetes Research and Care, III(12), 1-7

Davis, M. (2010). Psychological Aspects of Diabetes Management. UK: Elsevier

Harraiter, J., \& Kautzky ,W. A. (2018). Sex and Gender Differences in Prevention of Type 2 Diabetes. Frontiers in Endocrinology, 9(220), 1-15

Keyes, C. L. (2013). Gender and Subjective Well Being in the United States: From Subjective Well Being to Complete Mental Health. In Kimberly V: Oxington (Ed.), Psychology of Stress(pp. 1-15). New York: Nova Science Publisher

Kusnanto, K. (2013). Pengembangan Model Self Care Management-Holistic Psychospiritual Care terhadap Respon Holistik Penderita Diabetes mellitus Tipe 2. Universitas Airlangga

Kusumadewi, M. D. (2011). Peran Stressor Harian, Optimisme dan Regulasi Diri terhadap Kualitas Hidup Individu dengan Diabetes Melitus Tipe 2. Psikoislamika Jurnal Psikologi Islam, 8(1), 43-62

Mahmoud, S. S.,Mahdy, M. H., Mahfouz M. S., Nada, I. S., Aqeeli, A. A., Darbi, M. A., \& Ahmed, A, E. (2018). Effect of Psychoeducational Program On HbA1cLevel and Health Related Quality of Life in Patients with Type 2 Diabetes Mellitus, Jazan, Saudi Arabia. Hindawi Biomed Research International , 3(1), 1 10. https://doi.org/10.1155/2018/6915467

Massey, C., Feig, E., \& Duque, S. H. (2017). Pschological Well Being and Type 2 Diabetes. Curr Res Diabetes Obes J, 4(4), 1-6

Mojahed, A., Fallah, M., Ganjali, A., \& Heidari, A. (2019). The Role of Social Support and Coping Strategies in Prediction of Psychological Well Being in Type 2 Diabetic Patients of Zahedan. Bali Medical Journal, 8(1), 281 - 286

Padila, P. (2012). Buku Ajar Keperawatan Medikal Bedah. Yogyakarta: Nuha Medika 
Peyrot, M., Rubin, R. R., Lauritzen, T., Snoeks, F. J., Matthews, D. R., \& Skovlund, S. E. (2005). Psychosocial Problems and Barriers to Improved Diabetes Management: Results of the Cross-National Diabetes Attitudes, Wishes and Needs (DAWN) Study. Diabetic Medicine, 1379-1385

Tirumalesh, M., \& Candraiah K. (2017). Pscychologocal Well Being among Diabetes Mellitus Patients. International Journal of Applied Science and Management, 3(8), 29-31

Tol, A., Baghbanian, A., Mohebbi, B., Shojaeizadeh, D., Azam, K., \& Esmaeeli, S. (2013). Empowerment Assessment and Influential Factors Among Patients with Type 2 Diabetes. J Diabetes Metab Disord

WHO. (2014). Diabetes: the Cost of Diabetes. Retrieved March 28, 2014, from http://www.who.int/mediacentre/factsheets/fs236/en/

Yulishati. (2014). Efektifitas Edukasi Diabetes Terpadu untuk Meningkatkan Efikasi Diri Pasien Diabetes Mellitus Tipe 2. Tesis. Tidak diterbitkan. Sumatera Utara: Fakultas Keperawatan Sumatera Utara. http://repository.usu.ac.id/handle/ $123456789 / 42401$

Zurita, J. N., Apolinar, L. M., Flores, M. L. A., Gonzalez, A. G., Ahumada, A. G. N., \& Gonzalez, N. C. (2018). Health and Quality of IIfe Outcomes Impairment Quality of Lifein Type 2 Diabetes Mellitus : A Cross Sectional Study. Jealth and Quality of Life Outcomes, 16(94), 1-7 